\title{
SKEMA AKTAN DAN STRUKTUR FUNGSIONAL A.J. GREIMAS DALAM CERITA ASAL MULO JAMBI TULO DAN JAMBI KECIK
}

\author{
Sovia Wulandari ${ }^{1)}$, Dimas Sanjaya ${ }^{2)}$, Ririn Dwi Anggraini ${ }^{3)}$, Khairunnisa ${ }^{4)}$ \\ 1), 2) , 3) dan $^{4)}$ Sastra Indonesia, Fakultas Ilmu Budaya, Universitas Jambi \\ soviawulandari@unja.ac.id \\ dimassanjaya5@yahoo.co.id
}

\begin{abstract}
ABSTRAK
Penelitian ini menganalisis skema aktan dan struktur fungsional dari teori A.J. Greimas dalam cerita rakyat Asal Mulo Jambi Tulo dan Jambi Kecik. Penelitian ini mendeskripsikan skema aktan dan struktur fungsional cerita rakyat Asal Mulo Jambi Tulo dan Jambi Kecik. Pendekatan yang dilakukan adalah kualitatif. Fokus analisis adalah unsur naratologis pembangun dari cerita rakyat Asal Mulo Jambi Tulo dan Jambi Kecik. Data penelitian diambil langsung ke lapangan pada tanggal November 2019, di RT 10 Kelurahan Jambi Kecik, Kecamatan Muaro Sebo, Kabupaten Muarojambi. Data dianalisis dengan metode kuantitatif deskriptif. Adapun langkah-langkah yang dilakukan pada penelitian ini yaitu: 1) Penelitian ke lapangan dengan metode simak dan rekam, 2) mentranskripsikan data, 3) menerjemahkan data ke bahasa Indonesia yang baik dan benar, 4) menvalidasi data, 5) menyajikan data. Hasil penelitian menunjukkan adanya skema aktan, yaitu, subjek, objek, pengirim, penerima, pembantu, dan penentang. Ditemukan pula struktur fungsional, yaitu, situasi awal, transformasi (tahap uji kecakapan, tahap utama, dan tahap kegemilangan), dan situasi akhir.
\end{abstract}

Kata kunci: skema aktan, sastra lisan 
Sovia Wulandari ${ }^{1)}$, Dimas Sanjaya ${ }^{2)}$, Ririn Dwi Anggraini ${ }^{3)}$, Khairunnisa $^{4)}$ : Skema Aktan dan Struktur Fungsional A.J Greimas dalm Cerita Asal Mulo Jambi dan Jambi Kecik

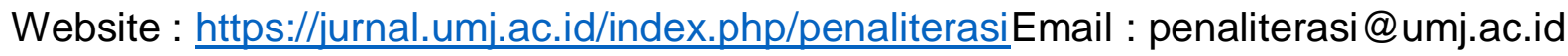

\section{PENDAHULUAN}

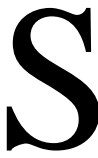

astra lisan adalah bagian tradisi lisan (folklore) yang berkembang di masyarakat dengan medianya yaitu bahasa. Tradisi lisan tesebut dibagi menjadi tiga yaitu, lisan, sebagian lisan dan bukan lisan. Contoh tradisi lisan yaitu cerita rakyat, puisi rakyat, dan petatah petitih. Tradisi sebagian lisan yaitu, teater rakyat, upacara adat, dan pantang larang. Sedangkan yang termasuk bukan lisan yaitu, keris, kain, kompangan dan sebagainya berupa benda yang biasanya berhubungan dengan tradisi lisan. Berdasarkan pengelompokan tersebut bahwa cerita rakyat termasuk ke dalam sastra lisan.

Cerita rakyat biasanya menisahkan aktivitas sehari-hari masyarakat. Cerita rakyat berguna untuk bahan refleksi masyarakat penutur dan pendengarnya. Cerita rakyat memiliki nilai didaktis yang dapat dipetik dan diilhami dalam kehidupan sehari-hari. Maka untuk menyampaikan pesan nilai-nilai tersebut, cerita rakyat memiliki unsur pembangun yang menarik. Unsur yang paling kontras ialah tokoh, selalu ada tokoh sebagai pembangun cerita yang bertentangan dan bermusuhan. Hierarki kehidupan hitam dan putih tampak jelas di dalam cerita rakyat pada umumnya.

Cerita rakyat dewasa ini cukup menarik dikaji oleh beberapa peneliti sastra dan budaya atau kritikus sastra. Penelitian tersebut guna melihat bentuk, isi, dan estetika dari cerita rakyat masa lampau. Lalu hasil penelitiannya adalah menjawab bagaimana transformasi karya sastra lama ke sastra modern. Kajian terkait keberadaan sastra lisan yang telah mengalami transformasi atau perubahan bentuk dari sastra lisan, kemudian menjadi sastra tulis setelah pemerintah mengupayakan pendokumentasian sastra lisan. Sastra lisan menjadi penting dikaji karena beberapa hal alasan yaitu, pertama, ia ada dan terus hidup di tengah masyarakat, tidak saja dalam masyarakat di daerah tertentu saja melainkan di seluruh daerah yang ada di Indonesia. Sastra lisan itu hidup pada masa masyarakat yang melahirkan dan menghidupkannya, di daerah kelahiran atau kampung asal (Juwati, 2018: 106).

Pengkajian sastra lisan mutakhir tidak seperti dulu yang penganalisisannya hanya berputar pada masalah unsur instrinsik, yaitu, tokoh, penokohan, latar, alur, dan aspek lainnya. Lebih dari itu strukturalisme yang relevan ialah naratologis atau strukturalismesemiotika. Menurut Sudjiman dan Zoest (1991: 5), semiotika adalah studi tentang tanda dan segala yang berhubungan dengannya, cara berfungsinya, dan mempergunakannya. Hakikat karya sastra sebagai dunia otonom menyebabkan karya sastra berhak untuk dianalisis, terlepas dari latar belakang sosial yang menghasilkannya. Sehubungan dengan hakikat otonomi, imajinasi dengan berbagai unsur yang berhasil diciptakan berhak untuk dianalisis secara ilmiah sebagai unsur-unsur dalam masyarakat sesungguhnya (Djirong, 2014: 216).

Daerah Melayu Jambi yang terbentang dari ujung Kerinci sampai Pesisir Tanjung Jabung, juga mempunyai kebudayaan yang membuat sebuah warna lokalitas Jambi. Dalam hal sastra, Jambi setidaknya punya cerita rakyat yang hingga saat ini sudah ditulis dalam bentuk baru (media) dan banyak dikaji di kalangan akademisi. Misalnya, Tapa Malenggang, Putri Tangguk, Uhang Pandak 
Sovia Wulandari ${ }^{1)}$, Dimas Sanjaya ${ }^{2)}$, Ririn Dwi Anggraini ${ }^{3)}$, Khairunnisa $^{4)}$ : Skema Aktan dan Struktur Fungsional A.J Greimas dalm Cerita Asal Mulo Jambi dan Jambi Kecik

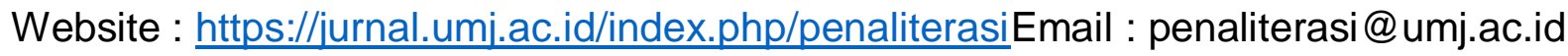

dan Putri Selero Pinang Masak. Terlepas dari karya yang sudah terkenal di Jambi, masih banyak cerita rakyat lain yang belum diketahui dan bahkan belum ditransformasikan dalam bentuk tulis.

Dalam penelitian ini, penulis menganalisis karya sastra lisan dengan judul Asal Mulo Jambi Tulo dan Jambi Kecik. Cerita rakyat ini berkembang di desa Jambi Tulo dan desa Jambi Kecik, Kecamatan Muaro Sebo, Kabupaten Muarojambi. Seperti pada umumnya cerita 'asal usul', cerita ini menceritakan awal atau sejarah yang diakui dan dianggap benar oleh masyarakat setempat mengenai awal mula terbentuknya dua desa tersebut. Cerita ini berkembang di masyarakat karena didukung oleh bukti-bukti yang dianggap benar oleh masyarakat setempat. Pelaku dan perbuatan yang dibayangkan benar-benar terjadi, menjadikan peristiwa dalam legenda seolah-olah terjadi dalam ruang dan waktu yang sesungguhnya. (Karim, 2016: 22).

Peneliti mencoba menganalisis menggunakan teori A.J. Greimas sebagai kajian awal. Teori tersebut biasa dikenal dengan teori strukturalisme naratologis. Teori membedah dongeng yang ada di Rusia lewat penelitian Greimas. Ia menyederhanakan teori fungsi Propp bahwasanya ada unsur fungsi yang utama disebut aktan sebagai pembagun cerita. Aktan inilah yang nantinya akan dianalisis menggunakan skema aktan. Setelah mendapatkan skema aktan akan dianalisis struktur fungsional dari cerita.
Strukturalisme naratologis A.J. Greimas merupakan kombinasi dari teori Vladimir Propp dan Levi's Strauss. Perbedaan dengan teori Propp, penelitian Greimas tidak terbatas pada dongeng, tetapi diperluas pada mitos. Greimas memfokuskan aksi (fungsi) dibandingkan dengan pelaku. Pada kategori subjek tidak bisa dibalik narasi, akan tetapi subjek atau manusia semu yang dibentuk oleh tindakan yang disebut sebagai aktan.

Greimas menyederhanakan fungsifungsi Propp (31 fungsi) menjadi dua puluh fungsi, kemudian dikelompokkan menjadi tiga struktur dalam tiga pasang oposisi biner. Teori Greimas ini merupakan penghalusan atas teori Propp. Propp telah memperkenalkan unsur naratif terkecil yang sifatnya tetap dalam sebuah karya sastra yang disebut sebagai fungsi (Todorov dalam Taum, 2011: 48).

Greimas dalam Taum (2011: 144) mengemukakan bahwa aktan adalah satuan naratif terkecil. Fungsi aktan yang terdiri atas enam aktan tersebut tampak dalam sebuah skema sebagai berikut:

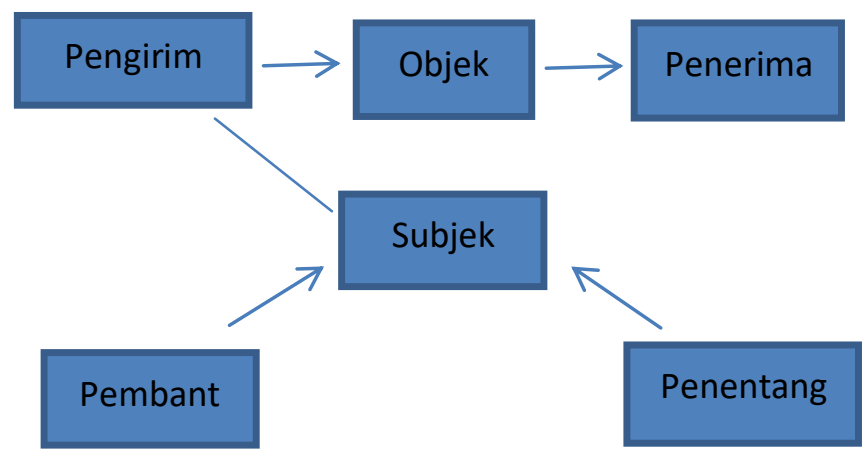

Skema 1. Aktan AJ. Greimas

Adapun fungsi atau kedudukan masing-masing aktan adalah sebagai berikut. Pengirim (sender) adalah aktan (seseorang atau sesuatu) yang menjadi sumber ide, 
Sovia Wulandari ${ }^{1)}$, Dimas Sanjaya ${ }^{2)}$, Ririn Dwi Anggraini ${ }^{3)}$, Khairunnisa $^{4)}$ : Skema Aktan dan Struktur Fungsional A.J Greimas dalm Cerita Asal Mulo Jambi dan Jambi Kecik

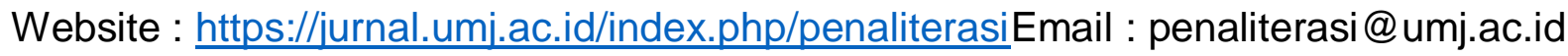

gagasan, dan berfungsi sebagai penggerak cerita. Objek (object) adalah aktan (sesuatu atau seseorang) yang dituju, dicari, diburu, atau diinginkan oleh subjek atas ide dari pengirim. Subjek (subject) adalah aktan pahlawan (sesuatu atau seseorang) yang ditugasi pengirim untuk mencari dan mendapatkan objek. Penolong (helper) adalah aktan (sesuatu atau seseorang) yang membantu atau mempermudah usaha subjek atau pahlawan untuk mendapatkan objek. Penentang (opponent) adalah aktan (sesuatu atau seseorang) yang menghalangi usaha subjek atau pahlawan dalam mencapai objek. Penerima (receiver) adalah aktan (sesuatu atau seseorang) yang menerima objek yang diusahakan atau dicari oleh subjek. (Zaimar, 1992: 19; Suwondo, 2003: 52-54).

Selain menunjukan skema aktansial Greimas dalam Taum (2011: 146) mengemukakan bahwa model cerita tetap sebagai alur. Model fungsional dibentuk dalam tabel berikut:

Tabel 1. Struktur Fungsional AJ. Greimas.

\begin{tabular}{|c|l|l|l|c|}
\hline I & \multicolumn{3}{|c|}{ II } & III \\
\hline \multirow{4}{*}{$\begin{array}{c}\text { Situasi } \\
\text { awal }\end{array}$} & Tahap Uji & Tahap & Tahap & \multirow{2}{*}{ Kecakapan } \\
\cline { 2 - 3 } & & Uji & Kegelimangan & akhir \\
& & Utama & & \\
\hline
\end{tabular}

Model fungsional dibagi menjadi tiga bagian, yaitu (1) situasi awal, (2) transformasi, dan (3) situasi akhir. Skema fungsional berdasar Greimas, yaitu dengan cara membaginya ke dalam bagian-bagian. Situasi awal yang menggambarkan keadaan awal peristiwa yang mengganggu keseimbangan (harmoni). Dalam tahap ini, subjek mulai mencari objek. Pada tahap ini, terdapat berbagai rintangan dan di situlah subjek mengalami uji kecakapan. Transformasi meliputi tiga tahap cobaan. Ketiga tahapan cobaan ini menunjukkan usaha subjek untuk mendapatkan objek. Dalam tahap ini pula muncul pembantu dan penentang. Tahap utama berisi gambaran hasil usaha subjek dalam mendapatkan objek. Dalam tahap utama ini, sang Pahlawan berhasil mengatasi tantangan dan melakukan perjalanan pulang. Sedangkan Situasi Akhir, tahap cobaan membawa kegemilangan merupakan bagian subjek dalam menghadapi pahlawan palsu. Misalnya, musuh dalam selimut atau seseorang yang berpura-pura baik padahal jahat, tabir pahlawan palsu terbongkar. Bila tidak ada pahlawan palsu, maka subjek adalah pahlawan. Sementara itu, situasi akhir berarti keseimbangan, situasi kembali ke keadaan semula. Di sinilah cerita berakhir dengan subjek yang berhasil mengalahkan objek.

Selain mencari unsur pembangun cerita, teori Greimas dapat pula menjawab relevansi sastra lisan terhadap kebudayaan setempat (Mustafa, 2017: 215). Relevansi sastra tersebut bisa dilihat dari simbol-simbol yang dihadirkan dalam cerita rakyat. Baik dari tokoh, benda-benda, aktivitas maupun ujaran tokoh.

Peneliti merumuskan masalah yaitu, bagaimana skema aktan dan struktur fungsional cerita rakyat Asal Mulo Jambi Tulo dan Jambi Kecik ?. Dari rumusan masalah, maka tujuan penelitian ini adalah untuk mengetahui skema aktan dan struktur fungsional cerita rakyat Asal Mulo Jambi Tulo dan Jambi Kecik. Setelah mengkaji cerita 
Sovia Wulandari ${ }^{1)}$, Dimas Sanjaya ${ }^{2)}$, Ririn Dwi Anggraini ${ }^{3)}$, Khairunnisa $^{4)}$ : Skema Aktan dan Struktur Fungsional A.J Greimas dalm Cerita Asal Mulo Jambi dan Jambi Kecik

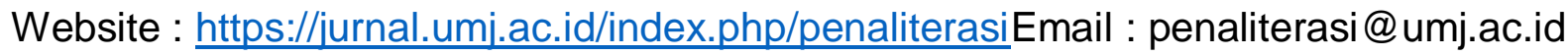

rakyat Asal Mulo Jambi Tulo dan Jambi Kecik, diharapkan dapat menambah manfaat, baik bagi peneliti maupun orang lain. Memberikan ruang kreatif khazanah Sastra Indonesia, dengan upaya memahami cerita rakyat melalui metode strukturalisme. Memberikan gambaran pada pembaca mengenai salah satu cerita rakyat yang ada di Muarojambi, yaitu, Asal Mulo Jambi Tulo dan Jambi Kecik. Mendorong pembaca untuk lebih meningkatkan dalam menggali cerita rakyat yang ada di daerah masing-masing, sehingga tumbuh keinginan untuk melestarikan cerita rakyat sebagai khazanah budaya.

\section{METODE PENELITIAN}

$\mathrm{P}$ enelitian ini menganalisis skema aktan dan struktur fungsional dari teori A.J. Greimas dalam cerita rakyat Asal Mulo Jambi Tulo dan Jambi Kecik. Pendekatan yang dilakukan adalah kualitatif. Menurut Moeleong, pendekatan kualitatif adalah mendeskrisipkan berupa kata-kata pada data yang ditemukan di lapangan. Fokus
Analisis adalah unsur naratologis pembangun dari cerita rakyat Asal Mulo Jambi Tulo dan Jambi Kecik. Data penelitian diambil pada tanggal 30 November 2019, di RT 10 Kelurahan Jambi Kecik, Kecamatan Muaro Sebo, Kabupaten Muarojambi. Data dianalisis dengan metode deskriptif. Adapun langkahlangkah yang dilakukan pada penelitian ini yaitu, 1)Penelitian ke lapangan dengan metode simak dan rekam. 2) mentranskripsikan data. 3) menerjemahkan data ke bahasa Indonesia yang baik dan benar. 4) menvalidasi data. 5) menyajikan data (Wulandari, 2019: 12-15).

\section{HASIL DAN PEMBAHASAN}

\section{Skema Aktan Cerita Asal Mulo Jambi Tulo} dan Jambi Kecik

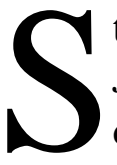
truktur aktan dalam cerita Asal Mulo Jambi Tulo dan Jambi Kecik ini dapat dikemukakan bahwa pengirim ditempati oleh Ahli Mujub; objek ditempati oleh Kaum Siluman dan; penerima ditempati oleh Penduduk Kampung; subjek ditempati oleh Temenggung Jakfar, pembantu ditempati oleh Istri Temenggung Jakfar dan penentang ditempati oleh Burung Beo.

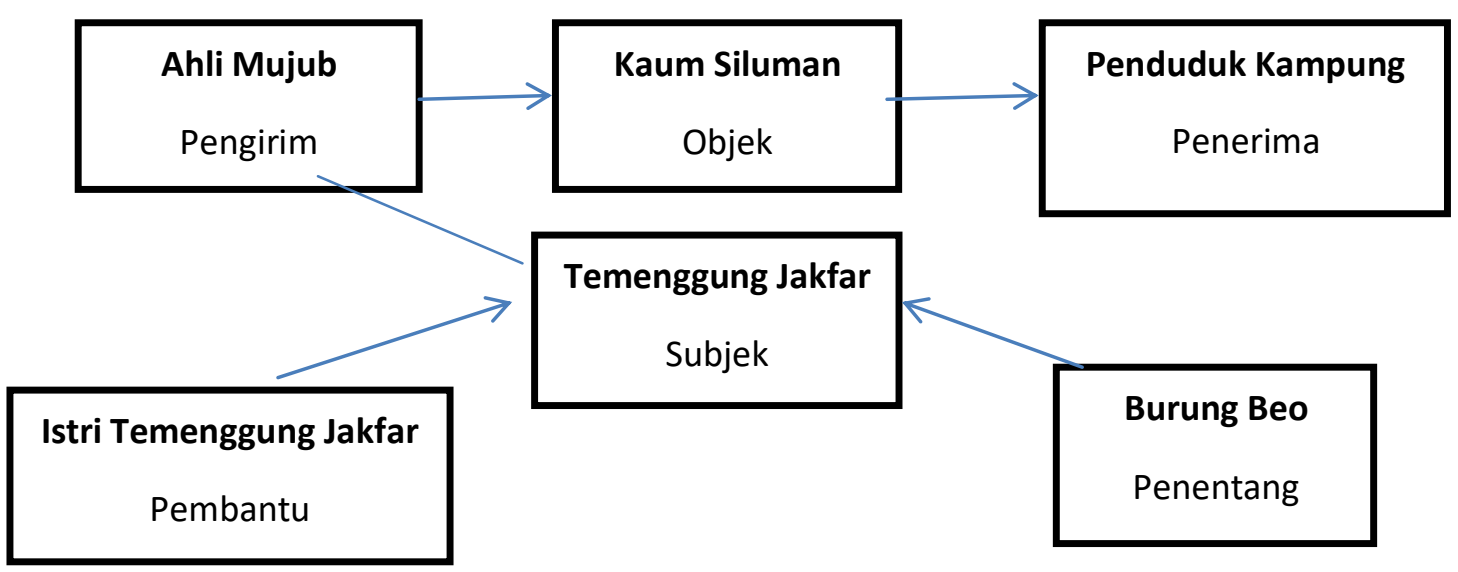


Sovia Wulandari ${ }^{1)}$, Dimas Sanjaya ${ }^{2)}$, Ririn Dwi Anggraini ${ }^{3)}$, Khairunnisa $^{4)}$ : Skema Aktan dan Struktur Fungsional A.J Greimas dalm Cerita Asal Mulo Jambi dan Jambi Kecik

Website : https://jurnal.umj.ac.id/index.php/penaliterasiEmail : penaliterasi@umj.ac.id

Skema 2. Skema Aktan pada Cerita Asal Mulo Jambi Tulo dan Jambi Kecik

Sesuai skema aktansial di atas, Ahli Mujub menduduki jabatan sebagai pengirim (sender), lewat mimpi-mimpi Ahli Mujub, Temenggung Jakfar selalu mengikuti mimpinya tersebut. Dimulai untuk hati-hati akan serangan kaum siluman dan memutuskan pindah dari Tumening. Akhirnya, Temenggung Jakfar memerintah penduduk kampung untuk pindah. Setelah pindah jauh, mereka istirahat. Ahli Mujub kembali bermimpi, dalam mimpinya ia memutuskan untuk menghentikan perjalanan dan kembali membangun kampung di tempat mereka istirahat tersebut.

Temenggung Jakfar memegang peranan sebagai subjek, artinya atas jiwa kepemimpinannya ia dalam hal ini dikelompokkan sebagai fungsi pahlawan. Lewat keputusan yang ia buat, ia telah menyelamatkan banyak nyawa penduduk kampung. Berkat ia pula, tidak terjadi perpecahan antar penduduk kampung karena padatnya penduduk. Ia membuat keputusan untuk membagi dua yaitu Jambi Tulo dan Jambi Kecik.

Cerita bergerak tidak hanya dari Temenggung Jakfar. Fungsi objek sebagai lawan dari subjek, memegang peranan bahwa selalu ada rasa iri dan dengki terhadap kesuksesan orang lain. Dalam cerita ini, disimbolkan sebagai kaum siluman. Kaum siluman bergerak dalam cerita sebagai lawan dari Temenggung Jakfar dan penduduk kampung. Temenggung Jakfar dalam hal dibantu oleh istrinya ketika ia berhasil ditemukan oleh kaum siluman. Istri Temenggung Jakfar memberikan ubi beracun (gadung). Kaum siluman dapat menemukan Temenggung Jakfar karena diberi tahu oleh Burung Beo yang merupakan peliharaan Temenggung Jakfar sendiri. Dalam hal ini, Burung Beo tersebut dikelompokkan sebagai fungsi penentang cerita. Setelah peristiwa dan konflik selesai. Desa kembali makmur sehingga fungsi Penerima (receiver) adalah Penduduk Kampung, sebagai fungsi yang merasakan hasil dari perjuangan (naratologis cerita).

\section{Struktur Fungsional}

Struktur fungsional adalah jalan cerita dari pengenalan, pemunculan masalah, dan penyelesaian masalah. Struktur fungsional cerita Asal Mulo Jambi Tulo dan Jambi Kecik adalah sebagai berikut:

\section{Situasi Awal}

Dalam cerita Asal Mulo Jambi Tulo dan Jambi Kecik, Temenggung Jakfar menempati posisi Subjek. Temenggung Jakfar berperan sebagi penggerak cerita dari awal hingga akhir. Pemunculan permasalahan kolektif tersebut dipimpin oleh Temenggung Jakfar yang mengajak untuk berlabuh ke Pesisir Batanghari dari pulau Jawa.

Pada suatu hari, di daerah Jawa, konon sudah padat pendduduk. Sehingga masyarakat pesisir Jawa memutuskan untuk pindah dari daerah tersebut mencari tempat hidup yang baru. Pada 
Sovia Wulandari ${ }^{1)}$, Dimas Sanjaya ${ }^{2)}$, Ririn Dwi Anggraini ${ }^{3)}$, Khairunnisa $^{4)}$ : Skema Aktan dan Struktur Fungsional A.J Greimas dalm Cerita Asal Mulo Jambi dan Jambi Kecik

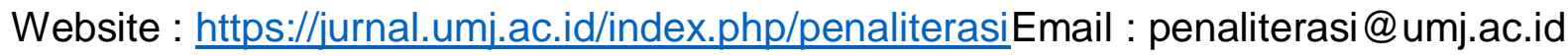

perjalanannya mereka membawa, ahli besi, ahli batu, ahli tanah, ahli gelombang, ahli mujub, dan ahli bangunan. Di daerah Tumening. Berawal dari perjalanan orang Jawa yang datang dari mataram. Dia dan rombongannya mau mencari kampung (tempat tinggal). Jadi setelah lama berjalan dan berlayar dengan menggunakan rakit dari bambu, sampai lah dia dan rombongannya di daerah tersebut. Dulu daerah itu masih laut semua. Dia mencari tanah kosong untuk di jadikan negeri. Tidak lama kemudian, dia menemukan tanah, tetapi tanah tersebut masih tertimbun di bawah laut, sesekali tanah itu menjadi daratan ketika air laut pasang. Akhirnya lama-kelamaan air launnya menyusut dan jadilah daratan. Dia dan rombongannya memberhentikan rakitnya di sana. Kemudian Temenggung Jakfar selaku ketua rombongan berbicara kepada rombongannya bahwa tanah inilah yang bakal menjadi kampung (tempat tinggal) mereka untuk melanjutkan kehidupan dan tak perlu lagi mencari tempat tinggal lain.karna di tampat ini la mereka memulai kehidupan lagi.

Kalimat di atas menjelaskan kondisi masyarakat pengikut Temenggung Jakfar yang pada saat itu harus berlabuh ke Pesisir Sungai Batanghari walaupun ditemukan secara tidak sengaja. Faktor perpindahan mereka yaitu sudah kehabisan bahan makanan sehingga mencari tempat baru. Pada kutipan di atas menjelasakan situasidan kondisi, serta alasan mereka pindah. Pada situasi awal juga dikenalkan para penduduk dan ahli-ahlinya. Secara logika, dengan ahli tersebut sangat masuk akal karena, ahli tersebut gunanya adalah untuk membangun kembali peradaban di tempat lain.

Pada situasi awal juga diceritakan bahwa Temuning awalnya adalah lautan yang lama kelamaan sejak mereka terdampar menjadi daratan. Air mulai surut sehingga diputuskan untuk melanjutkan hidup di sana. Berkat bijaksananya keputusan Temenggung Jakfar, kampung yang mereka tinggali menjadi makmur. Kemakmuran tersebut tak lepas dari para ahli yang mereka bawa yaitu, ahli besi, ahli batu, ahli tanah, ahli gelombang, ahli mujub, dan ahli bangunan.

Tranformasi, dibagi tiga:

a. Tahap uji kecakapan

Pada tahap ini masalah mulai muncul, terlihat sebagai berikut

Kemudian di tempat baru ini juga temenggu dan rombongannya membangun rumah-rumah dan bertani. Mereka membangun rumah menggunakan bambu karna di dekat sana terdapat banyak pohon bambu dan oleh karena itu mereka membangun rumah dan membuat pagar yang mengelilingi kampung tempat tinggal mereka. Sehingga orang dari luar kampung tidak dapat masuk ke kampung tersebut.dan kampung tersebut pun makmur, mulai dari penduduk yang makmur, pertaniannya 
Sovia Wulandari ${ }^{1)}$, Dimas Sanjaya ${ }^{2)}$, Ririn Dwi Anggraini ${ }^{3)}$, Khairunnisa $^{4)}$ : Skema Aktan dan Struktur Fungsional A.J Greimas dalm Cerita Asal Mulo Jambi dan Jambi Kecik

Website : https://jurnal.umj.ac.id/index.php/penaliterasiEmail : penaliterasi@umj.ac.id

hingga

peternakan

mereka.sehingga membuat sebuah

kampung iri terhadap kampung

yang didirikan oleh temenggung.

Kalimat di atas menjelaskan keberhasilan Temenggung Jakfar dan Penduduk Kampung dalam membangun kampungnya. Setelah kampung dibangun, penduduk Temuning memutuskan untuk membuat pagar di sekeliling kampung agar tidak ada yang menggangu kehidupan penduduk Temuning. Dibangun pagar menambah keirian dari Kaum Siluman. Kaum siluman mencari akal agar dapat menyerang dan membunuh seluruh penduduk Temuning.

Para tokoh dalam cerita di uji "kecakapannya", dalam artian cara dan hasil yang dilakukan akan dilawan dengan kecemburuan. Layaknya representasi kehidupan bertetangga saat ini, yang iriirian terhadap keberhasilan orang lain. Maka setidaknya dari uji kecakapan ini, pendengar atau pembaca dapat mengambil hikmah dari sebuah kecakapan.

b. Tahap utama

Di tahap klimaks terjadi ketika penduduk Temuning diserang oleh kaum siluman yang iri pada kampung mereka.

Kampung Siluman tersebut ialah kampung yang mana orang-orang yang ada di kampung tersebut orang-orang yang suka berjudi, mabuk-mabukan,dan tidak bekerja.orang-orang tersebut iri melihat kampung yang makmur tersebut.berbagai cara mereka lakukan untuk dapat masuk dan menguasai kampung makmur tersebut tetapi usaha mereka selalu gagal.tanpa kehabisan akal akhirnya mereka menggali tanah di sebelah pagar bambu tersebut untuk di jadikan jalan ke kampung makmur.tanah yang orang-orang itu gali berbentuk terowongan,dan akhirnya orang-orang itu dapat masuk ke kampung tersebut lewat terowongan yang mereka gali.

Setelah mereka masuk ke kampung itu bertemula mereka pada penduduk yang ada di kampung tersebut.tetapi mereka kesana untuk mencari raja mereka yang membangun dan memimpin perkampungan itu.yang mana raja atau orang yang memimpin kampung tersebut adalah temenggung Jakpar.temenggu japar orang islam.

Mereka mencari tempat tinggal temenggung di kampung tersebut.dan akhirnya ketemu tempat tinggal temenggung tetapi nampaknya temengggu tidak ada di rumah. Kebetulan temenggung memeiliki butung beo. Dan akhirnya mereka yang mencari temenggun bertanya kepada burung beonya.

"Kemano tuanmu?", tanya para Kaum Siluman, Burung Beo itu pun menjawab "Di kamar".

Kalimat di atas menandakan situasi genting dan konflik. Kaum siluman mencari cara agar bisa masuk ke Kampung Temuning dengan cara menggali lobang yang dari desanya menuju desa Temuning. Setelah berhasil masuk ke kampung Temuning, Temenggung Jakfar yang sudah 
Sovia Wulandari ${ }^{1)}$, Dimas Sanjaya ${ }^{2)}$, Ririn Dwi Anggraini ${ }^{3)}$, Khairunnisa $^{4)}$ : Skema Aktan dan Struktur Fungsional A.J Greimas dalm Cerita Asal Mulo Jambi dan Jambi Kecik

Website : https://jurnal.umj.ac.id/index.php/penaliterasiEmail : penaliterasi@umj.ac.id

mengetahui atas mimpi Ahli Mujub, akhirna bersembunyi di dalam kamar. Akan tetapi, persembunyiannya diketahui Kaum Siluman berkat mereka bertanya kepada Burung Beo.

Saat berhasil ditemukan Temenggung Jakfar oleh kaum siluman, Temenggung Jakfar tetap tenang. Ia mencoba menenangkan suasana. Berkat jiwa kebijaksanaannya, ia mencoba merayu Kaum Siluman untuk bermusyawarah jangan main hakim. Kaum siluman tersebut akhirnya mau diajak musyawarah. Pada situasi ini, istri Temenggung Jakfar menjadi penolong (helper). Ia menyajikan gadung (ubi jalar rebus beracun), setelah dimakan oleh kaum siluman. Akhirnya, para kaum siluman itu mati.

c. Tahap Kegemilangan

Dan saat bermusyawarah datang lah istri temenggung ini memberikan gadung. Gadung ini sejenis ubi jalar yang di rebus. Tetapi saat orang-orang tersebut memakan gedung yang di bawakan istri temenggu . orang-orang itu mabuk dan akhirnya meninggal.

Tetapi penduduk di kampung itu bingung mau di kuburkan dimana mayat-mayat mereka. Dan salah satu penduduk kampung itu melihat lubang yang di gali oleh kaum siluman. Akhirnya penduduk tersebut memutuskan untuk mengubur mayat mereka semua di dalam lubang tersebut.setelah masalah tersebut selesai muncul lah masalah baru yang mana datang lah wabah penyakit membuat satu persatu penduduk di kampung itu meninggal akibat wabah tersebut.

Akhirnya pun temenggung membuat keputusan dan berbicara kepada penduduk kampung tersebut,

"Jadi dari pada kita meninggal satupersatu di kampung ini lebih baik kita pergi dari kampung ini dan mencari tempat tinggal yang baru”.

Akhirnya berangkatlah rombongan temengung ini.mereka berjalan berharihari dan akhirnya mereka menemukan sebuah sungai, berhentilah mereka untuk beristirahat dan tidur sebentar.di antara rombongan temenggu tersebut ada seorang ahli mujub (dukun/pawang).

Tahap kegemilangan ini, ialah saat Temenggung Jakfar, istri dan penduduk kampung berhasil mengalahkan kaum siluman. Mereka bersama-sama berkolaborasi untuk mengalahkan kaum siluman. Hal ini sesuai dengan teori Greimas, bahwa kaum siluman pada fungsi objek merupakan lawan dari subjek yaitu Temenggung Jakfar. Istri Temenggung sebagai fungsi penolong membantu Temenggung Jakfar karena hampir dibunuh oleh kaum siluman berkat diberi tahu oleh Burung Beo yaitu sebagai fungsi penentang. 
Sovia Wulandari ${ }^{1)}$, Dimas Sanjaya ${ }^{2)}$, Ririn Dwi Anggraini ${ }^{3)}$, Khairunnisa $^{4)}$ : Skema Aktan dan Struktur Fungsional A.J Greimas dalm Cerita Asal Mulo Jambi dan Jambi Kecik

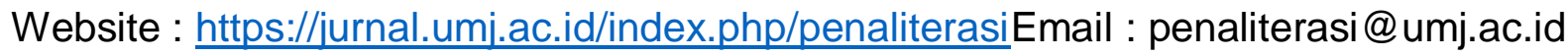

Penduduk Temuning pergi mencari desa lain, ia berhenti kembali di pesisir sungai yang panjang. Mereka memutuskan untuk hidup di sana berkat mimpi dari Ahli Mujub. Bahwa kegemilangan tidak serta merta membawa positif. Pembunuhan kaum siluman dan dikubur di lobang yang digali kaum siluman ternyata menyebabkan wabah penyakit. Seharusnya Penduduk Temuning merayakan euforia atas kemenangan. Tetapi malah menyebabkan mereka untuk kembali berlabuh mencari kampung lain.

\section{Situasi Akhir}

Pada tahap ini menceritakan konklusi sebab-akibat setelah terjadi peristiwa atau konflik dalam cerita.

Di saat itu lah salah satu buah pinang jatuh mengenai kepala Ahli Mujub yang sedang tertidur, sehingga membuat si Ahli Mujub tersebut terbangun.kemudian ahli mujub pun berbicara kepada temenggung selaku pemimpin rombongan. I menceritakan semua yang orang tua tadi bicarakan di dalam mimpinya. Temenggung pun setuju dan akhirnya .temenggung berbicara kepada rombongan nya dan rombongannya pun setuju.

Keesokan harinya temenggung dan rombongannya mulai bergotong royong untuk membangun kampung (tempat tinggal) mereka kembali. Mereka menebang semua pohon yang ada tetapi tidak menebang pohon pinang yang tinggi itu.mereka memulai kehidupan baru mulai bertani lagi sehingga kampung yang di pimpin temenggung itu makmur lagi.

Setelah itu temenggung dan penduduk kampung tersebut berkumpul dan bermusyawarah untuk mencari nama kampung yang mereka tempati saat ini.

"Jadi,sekarang ini kita udah ada kampung untung tempat tinggal kita,tetapi kampung ini belum memiliki nama,menurut kalian nama apa yang cocok untuk kampung kita ini" Tanya temenggung kepada penduduk kampung yang berkumpul.

"Mudah saja, kita kan orang jawa, dan ini kan pohon pinang (sambil menunjuk pohon pinang yang ada di sebelah nya).dan pohon pinang ini. Nampaknya sudah tua karena pohon ini sangat tinggi, dan bahasa jawa nya pohon pinang jambe nah kita buat saja namanya jambi tuo" jawab si Ahli Mujub.

Maka jadilah nama kampung tersebut "Jambi tuo" yang mana akhirnya kampung tersebut sangat makmur. Setelah lama-kelamaan nama kampung tersebut pun berubah menjadi "jambi tulo" beriringnya waktu akhirnya tanah kosong yang ada di sebelah kampung tersebut pun, di buat lagi kampung baru dan dipagari oleh pohon-pohon pinang yang menjadi pagar dan mengelilingi kampun baru tersebut, sehingga temenggung 
Sovia Wulandari ${ }^{1)}$, Dimas Sanjaya ${ }^{2)}$, Ririn Dwi Anggraini ${ }^{3)}$, Khairunnisa $^{4)}$ : Skema Aktan dan Struktur Fungsional A.J Greimas dalm Cerita Asal Mulo Jambi dan Jambi Kecik

Website : https://jurnal.umj.ac.id/index.php/penaliterasiEmail : penaliterasi@umj.ac.id

pun menamai kampung baru tersebut dengan jambe kecik, karena dikelilingi pinang yang masih kecil (muda).

Penggalan akhir cerita tersebut, menjelaskan kepada pembaca atas kegigihan dan kepemimpinan Temenggung Jakfar, ia berhasil menyelamatkan banyak nyawa penduduk kampungnya. Setidaknya dua kali peristiwa mereka berpindah tempat menandakan bahwa cerita yan beralur maju ini dapat berhasil dijalani dengan kebersamaan. Beberapa simbolisasi kebersamaan seperti, mengayuh satu rakit, bekerja sesuai porsi untuk membangun peradaban dan musyawarah mufakat.

Sesuai dengan judul cerita Asal Mulo Jambi Tulo dan Jambi Kecik, di dalam cerita dijelaskan bahwa kata jambi diambil dari jambe yang artinya pinang berasal dari bahasa Jawa. Kata tulo diambil dari tuo. Hal itu diambil dari pagar kampung tersebut dikelilingi Pinang yang sudah tuo. Maka jadilah nama "Jambi Tulo". Asal mula nama Jambi Kecik, karena penduduk Jambi Tulo sudah banyak dan padat. Akhirrnya mereka membuka lahan baru, dan kembali dipagari pohon pinang. Karena masih baru pohon pinang tersebut masih muda. Sehingga dinamakan desa tersebut yaitu Jambi Kecik.

\section{KESIMPULAN}

etelah menganalisis cerita Asal Mulo Jambi Tulo dan Jambi Kecik, disimpulkan bahwa skema aktan yang di dalamnya ada beberapa fungsi ternyata dapat pula digunakan sebagai analisis dalam cerita ini. Oposisi biner yang dijelaskan A.J. Greimas terhadap kajiannya, dapat pula dijelaskan dalam cerita ini. Fungsi subjek yang berlawanan dengan objek tampak jelas dalam cerita. Temenggung Jakfar (subjek) berhasil mengalahkan kaum Siluman (objek). Temenggung Jakfar tentunya dibantu oleh Istrinya (helper), Istri Temenggung sebagai fungsi Penolong membantu Temenggung Jakfar karena hampir dibunuh oleh kaum siluman berkat diberi tahu oleh Burung Beo yaitu sebagai fungsi penentang. Ahli Mujub sebagai pengirim (sender) informasi terhadap mimpi-mimpinya, sebagai perpanjangan tangan Temenggung Jakfar dalam mengalahkan kaum Siluman. Pada akhirnya, setelah kaum Siluman sebagai objek atau lawan utama dalam cerita, kalah dengan Temenggung Jakfar. Fungsi penerima atau yang merasakan kebahagiaan setelah selesainya konflik adalah penduduk kampung.

Pada struktur fungsional, pada umumnya sama dengan cerita rakyat lain. Situasi awal yaitu, masyarakat yang kekurangan akan wilayah dan bahan baku makanan memustuskan untuk pindah mencari tempat untuk kehidupan baru. Tahap Tranformasi, di tahap ini konflik mulai bermunculan dari pengenalan konflik hingga penyelesaiannya (klimaks ke antiklimaks). Dan Situasi Akhir, yaitu masalah selesai dan akhirnya mencari kembali tempat yang aman. Pada situasi akhir dijelaskan dari mana asal nama Jambi 
Sovia Wulandari ${ }^{1)}$, Dimas Sanjaya ${ }^{2)}$, Ririn Dwi Anggraini ${ }^{3)}$, Khairunnisa $^{4)}$ : Skema Aktan dan Struktur Fungsional A.J Greimas dalm Cerita Asal Mulo Jambi dan Jambi Kecik

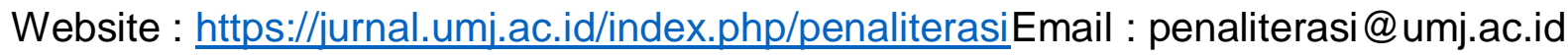

Tulo dan Jambi Kecik. Jambi yang artinya pinang dalam bahasa Jawa, tulo artinya tua dan kecik artinya muda.

Dari hasil analisis membuktikan bahwa teori Greimas dapat digunakan dalam cerita rakyat di Indonesia. Skema aktan dan fungsional Greimas dapat menjawab atas naratologis dalam cerita rakyat.

\section{UCAPAN TERIMA KASIH}

7 erima kasih kepada Datuk Mukhtar Hendro yang telah berbagi cerita (data) demi kelancaran penelitian kami. Semoga ini menjadi tonggak untuk penelitian selanjutnya yang lebih mendalam. Begitu pula dengan proses pendokumentasian sastra lisan di Jambi dapat dinikmati oleh khalayak ramai.

\section{REFERENSI}

Djirong, Salmah. 2014. Kajian Antropologi Sastra: Cerita Rakyat Datu Museng dan Maipa Diapati. Jurnal Sawerigading, Vol. 20 No.2, Agustus 2014, hlm. 215-226.

Juwati. 2018. Sastra Lisan Bumi Silampari: Teori, Metode, dan Penerapannya. Yogyakarta: Deepublish Publisher.
Karim, Maizar. 2015. Menyelisik Sastra Melayu. Yogyakarta: Histokultura.

Mustafa. 2017. Skema Aktan dan Fungsional Cerita Sangbidang. Jurnal Sawerigading, Vol. 23 No. 2, Desember 2017, hlm. 205-216.

Sudjiman, P, dan Aart Van Zoest, A. V. 1991. Serba-Serbi Semiotika. Jakarta: Gramedia.

Suwondo, Tirto. 2003. Studi Sastra Beberapa Alternatif. Yogyakarta: Hanindita.

Taum, Yoseph Yapi. 2011. Studi sastra lisan: Sejarah, Teori, Metode, dan Pendekatan Disertai Contoh Penerapannya. Yogyakarta:

Lamalera

Wulandari, Sovia. 2019. Panduan Penelitian Sastra Lisan, Program Studi Sastra Indonesia FIB UNJA. Bahan Ajar Perkuliahan Kajian Sastra Lisan. Jambi: Unja.

Zaimar, Okke K.S. 1991. Menelusuri Makna Ziarah Karya Iwan Simatupang. Jakarta: Intermasa. 